\title{
Dietary changes and histophysiological responses of a wild fish (Geophagus cf. proximus) under the influence of tilapia cage farm
}

\author{
Bruna Caroline Kotz Kliemann ${ }^{\mathrm{a}, *}$, Rosilene Luciana Delariva ${ }^{\mathrm{b}}$, João Paulo de Arruda Amorim ${ }^{\mathrm{b}}$, \\ Cristiéle da Silva Ribeiro ${ }^{a}$, Bruno da Silva ${ }^{a}$, Rosicleire Veríssimo Silveira ${ }^{a}$, Igor Paiva Ramos ${ }^{a}$ \\ a Universidade Estadual Paulista “Júlio Mesquita Filho”, UNESP- FEIS- Campus Ilha Solteira, Rua Monção, 226, Zona Norte - Ilha Solteira, São Paulo, Brazil \\ ${ }^{\mathrm{b}}$ Universidade Estadual do Oeste do Paraná, UNIOESTE_Campus Cascavel, Rua Universitária, 2069, CEP 85819-110, Cascavel, Paraná, Brazil
}

\section{A R T I C L E I N F O}

Handled by B. Morales-Nin

Keywords:

Environmental influence

Aquaculture

Trophic ecology

Metabolism

Histopathology

\begin{abstract}
A B S T R A C T
The influence of cage fish farm on the trophic, histopathological and metabolic aspects of a wild fish species (Geophagus cf. proximus) was evaluated considering diet, liver histopathology and the concentration of total proteins in the liver, gonads and muscles in fish from two sampling areas (cage farm and control). Diet composition and trophic niche breadth differed significantly between the sampling areas. Detritus, aquatic plants and Cladocera composed the diet in the control area, while mollusks and pelleted feed, followed by detritus, were highly representative of the diet of fish in the cage farm area. More severe histopathological alterations were found in the specimens collected in the cage farm area. These alterations include severe pancreatic hyperplasia and hepatic steatosis. Total protein concentrations in muscles showed no significant difference between the areas. For the liver, the highest concentration was found in fish from the cage farm area, whereas for gonads, higher values were detected in the fish from the control area. These results show that there were hepatic and gonadal metabolic changes in farm-associated specimens compared to specimens from the control area. The high protein and lipid contents of the diet promoted severe histopathological alterations in the liver, impairing hepatic function and possibly interfering in the mobilization of proteins to the gonads. Thus, the relationship between dietary changes and histophysiological alterations suggests an influence of cage fish farm on the ecology of farm-aggregated fish species.
\end{abstract}

\section{Introduction}

Brazil is one of the largest agricultural markets in the world and has an emphasis on zootechnical activities related to aquaculture, with estimates of growth of more than $100 \%$ by 2025 (Kubitza, 2015; FAO, 2016). The tropical climate and high availability of water resources, represented by more than $8500 \mathrm{~km}$ of coastline and 4.2 million hectares of water dammed in reservoirs, favor Brazilian aquaculture (Borges, 2014; Kubitza, 2015). These factors have led to the rapid growth of aquaculture and have raised questions about the potential environmental effects caused by this activity.

The most important type of aquaculture is cage fish farm, which in Brazil is usually carried out in the reservoirs of hydropower plants (Abrunhosa, 2011). Species successfully cultivated in these enterprises include tambaqui (Colossoma macropomum), tambacu (Colossoma sp. $\times$ Piaractus sp.), pacu (genus Piaractus), carp (Cyprinus carpio, Aristichthys nobilis, Ctenopharyngodon idella) (Abrunhosa, 2011) and tilapia (Oreochromis niloticus and its lineages) (Kirchner et al., 2016;
Schulter and Vieira Filho, 2017). Oreochromis niloticus is the second most cultivated species worldwide, and it is the most abundantly produced fish species in Brazilian aquaculture $(219,329$ tons $=45.4 \%$ of fish production in 2015) (IBGE, 2015).

Cage fish farm in freshwater ecosystems is an intensive cultivation model in which fish are stored at high density, confined in floating structures in natural or semi-natural aquatic systems and provided with an intense pelleted feed supply, thus requiring continuous water renewal (Agostinho et al., 2007; Abrunhosa, 2011). This production model is known to cause changes in hydrological dynamics and the physical and chemical characteristics of the water, strongly interfering with habitat availability and quality and environmental trophic status (Agostinho et al., 2007; Tundisi, 2007). In this sense, cage fish farm in freshwater ecosystems represents additional influences in places that are already subject to changes in their environmental characteristics, fauna and flora (Ramos et al., 2008). This mode of production promotes several abiotic and biotic changes in the aquatic ecosystems used for this purpose and in adjacent areas.

\footnotetext{
* Corresponding author.

E-mail address: bruna.kliemann@unesp.br (B.C.K. Kliemann).
} 


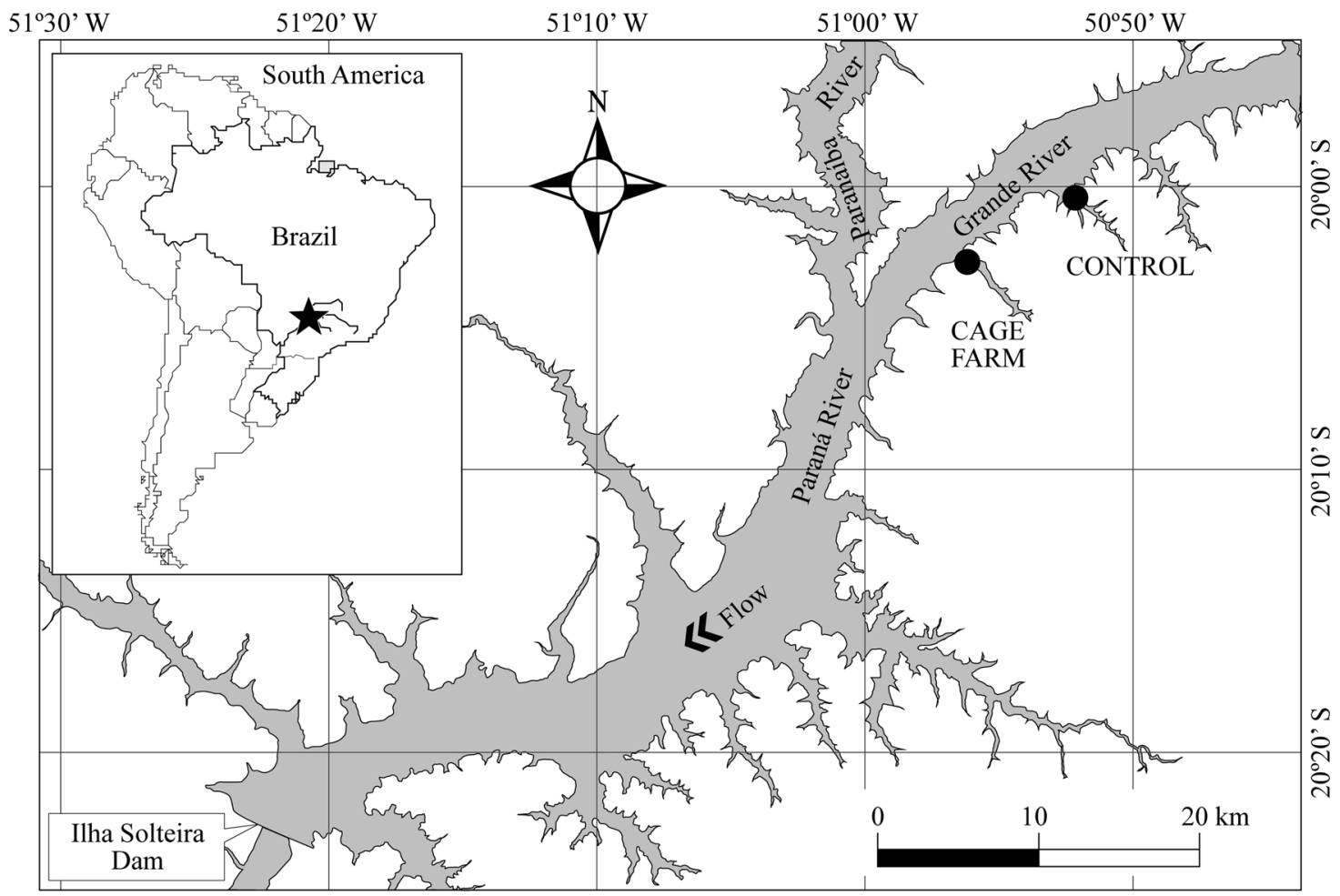

Fig. 1. Study area: Grande River, Ilha Solteira Reservoir, State of São Paulo, Brazil.

Studies on cage fish farm in freshwater systems have demonstrated changes in wild fish species on reproductive aspects of Pimelodus maculatus (Brandão et al., 2014) and influence parasitological factors in Plagioscion squamosissimus (Ramos et al., 2014). In addition, interference in settlement patterns has also been reported (Agostinho et al., 2007; Mallasen et al., 2012) due to the input of organic matter from cages and the introduction of non-native species (Zanatta et al., 2010), mainly through fish escaping from cultivation (Agostinho et al., 2007). As a consequence, there may be changes in the population dynamics of wild fish with the aggregation of fish in these areas (Ramos et al., 2013; Brandão et al., 2013; Ortega et al., 2015), as well as interference with the trophic ecology (Brandão et al., 2012; Ramos et al., 2013, Edwards, 2015) and the nutritional condition of fish (increased condition factor values) (Ramos et al., 2013; Ortega et al., 2015), when fish, mainly omnivores, feed on available food pellets.

Influences on the diet and fatty acid composition of wild fish due to feed on food pellets in the area around cage fish farm has also been reported for marine environments (Fernandez-Jover et al., 2007; Fernandez-Jover et al., 2011; Arechavala-Lopez et al., 2011). In addition, morphophysiological alterations in the organs of fish caused by the consumption of the food pellets have also been reported (Ségade et al., 2015; Zhang et al., 2017). Therefore, histophysiological studies conducted in conjunction with dietary assessments are efficient tools for detecting alterations in tissues and organs that result from changes in diet (Bernet et al., 1999; Baldisserotto, 2013). Moreover, they allow the visualization of biotic and abiotic effects on physiological functions such as nutrition, growth and reproduction (Saraiva et al., 2015, Yancheva et al., 2016). These tools can help build an understanding of the influence of freshwater cage fish farm on wild biota.

One of the ways to identify histophysiological effects is by quantifying cellular changes in organs, such as the liver, and changes in levels of metabolites, such as total protein contents. The liver plays a key role in the mobilization and metabolism of food molecules and is essential for organisms in detoxification (Bernet et al., 1999; Shiogiri et al., 2012; Yancheva et al., 2016). Morphofunctional alterations in the liver reflect the physiological responses of other organs, such as muscles and gonads. The function of the musculature is directly linked to the swimming performance and anaerobic condition of the fish (Mommsen, 2001), which his directly related to the ability to capture food and avoid predators. At the reproductive level, metabolic and histophysiological changes in the gonads can directly affect the success of vitellogenesis, the recruitment of oocytes and spawning, with consequences for the long-term maintenance of viable natural populations (Baldisserotto et al., 2014).

Studies related to the concomitant effects of dietary changes and histophysiological responses in wild populations of fish subjected to the effects of cage fish farm are lacking in the Neotropical region. Thus, omnivorous fishes with high trophic plasticity and a strong ability to adapt to anthropogenic environments, such as Geophagus cf. proximus (Castelnau, 1855), are good models to evaluate the effects of interference from cage fish farm on wild biota. This species was introduced through cage fish farm (Langeani et al., 2007) and is one of the most abundant species in the Ilha Solteira Reservoir.

In this context and considering that the pelleted feed supplied to fish in cage farms has high protein and lipid contents and that there is a surplus of this material in the surrounding aquatic environment, it was hypothesized that direct pelleted feed intake causes changes in the liver at the level of tissues and cells, as well as changes in metabolite concentrations. This study had the following objectives: i) to evaluate the diet of $G$. cf. proximus and determine if the species consumes surplus pelleted feed in the area surrounding cage fish farm; ii) to check if the consumption of surplus pelleted feed influences the condition of this species; iii) to analyze whether there are structural alterations in hepatic tissue in this species due the high concentration of proteins and lipids in artificial pelleted feed; and iv) to verify the physiological responses, as reflected by total protein concentrations in the muscles, gonads and liver, in specimens that consume pelleted feed. 


\section{Material and methods}

\subsection{Study area}

The Ilha Solteira Reservoir is an accumulation reservoir formed by the Paraná River in the region of the Upper Paraná River (Fig. 1). It has an average depth of $17.6 \mathrm{~m}$, a maximum volume of $21.06 \times 10^{9} \mathrm{~m}^{3}$, a basin area of $1195 \mathrm{~km}^{2}$ and a residence time of 46.7 days (Garcia et al., 2014). In this reservoir, there are approximately 80 cage fish farms (inf. pess. CATI of Santa Fé do Sul municipality). The studied fish farm is located in the Can-Can arm of the reservoir (Fig. 1). Currently, the fish farm rears Nile tilapia ( $O$. niloticus) and has approximately 230 cages that are $18 \mathrm{~m}^{3}$ and 18 cages that are $144 \mathrm{~m}^{3}$, with pelleted feed provided at a rate of $4375 \mathrm{~kg} /$ day. The pelleted feed used contains approximately $32 \%$ crude protein, $10 \%$ mineral matter, $6 \%$ ether extract, $5 \%$ fiber matter, $3.5 \%$ calcium, $1.5 \%$ phosphorus, and vitamins and other minerals in smaller proportions.

\subsection{Field collection}

The collection of specimens of $G$. cf. proximus was carried out in April 2016 using gill nets with different mesh sizes $(3-16 \mathrm{~cm}$ between nonadjacent knots), which were left out for approximately $14 \mathrm{~h}$. Sampling was conducted in two areas with similar characteristics in terms of hydrodynamics and temperature: one within the area used for cage fish farm (cage farm area) and the other approximately $10 \mathrm{~km}$ upstream, without any influence from the cage fish farm (control area) (Fig. 1).

Voucher specimens were deposited in the fish collection of Universidade Estadual Paulista "Júlio de Mesquita Filho" (DZSJRPPisces 8898).

\subsection{Laboratory procedures}

\subsubsection{Diet}

The collected specimens were placed individually in plastic bags and gradually cooled to rapidly decrease their metabolic activity until death according to SISBIO authorization number 42229-1. The procedure was approved by the Ethics Committee on Animal Experimentation of the Universidade Estadual Paulista "Júlio de Mesquita Filho", authorization number 001/2014.

The specimens were identified (Graça and Pavanelli, 2007) and were measured with regard to standard length $(\mathrm{cm})$ and total weight (g). Subsequently, their stomachs and intestines were removed and fixed in a $4 \%$ formaldehyde solution. The stomach contents were examined under an optical stereomicroscope. Food items were identified using the identification keys of Bicudo and Bicudo (1970) for algae and of Mugnai et al. (2010) for invertebrates and were quantified according to the volumetric method; i.e., the total volume of a food item taken by the fish population is given as a percentage of the total volume of all stomach contents (Hyslop, 1980), with measurements made using graduated test tubes and a glass counting plate (Hellawell and Abel, 1971).

\subsubsection{Histological analysis}

Eight adult specimens of $G$. cf. proximus were selected from each sampling area. The livers were removed and fixed by immersion in a Karnovsky solution (Abrahão et al., 2004). After fixation, the tissues were dehydrated in an increasing ethanol series, cleared in xylene and embedded in Paraplast (Sigma-Aldrich - USA). Semi-serial cross-sections and longitudinal sections of $5 \mu \mathrm{m}$ thickness were obtained with an Olympus CUT 4060 microtome (MicroTec- Germany). The sections were stained with Harris hematoxylin and eosin (HE). All sections were observed using a Olympus BX60 photomicroscope (Olympus, Melville, $\mathrm{NY}$ ), and the images were recorded using a digital camera DP71 and DP controller 3.2.1.276 software (Olympus, Melville, NY).

\subsubsection{Quantification of total proteins}

The total protein concentration was determined for 10 samples (one per specimen) of liver, gonad and muscle tissue from each area (cage farm and control). The total protein content of each of these tissues was measured according to the method of Lowry et al. (1951). Precipitation and solubilization were performed as described by Milligan and Girard (1993). Total protein concentrations were measured in a spectrophotometer at $660 \mathrm{~nm}$ based on a standard curve generated from bovine serum albumin (Sigma Diagnostics INS, St. Louis, MO, USA).

\subsection{Data analysis}

To test for possible significant differences in standard length was compared between fish from the sampling areas by the Mann-Whitney test ( $U$ test).

To test for possible significant differences in diet composition between fish from the cage farm and control areas, a permutational multivariate analysis of variance (PERMANOVA) was applied using the Bray-Curtis index, with 9999 random permutations (Anderson, 2001). Food items responsible for the differences between the areas (cage farm and control) were evaluated using the similarity percentage method (SIMPER). All possible pairs of samples were compared using the BrayCurtis measure (Clarke, 1993).

A multivariate homogeneity of dispersion test (PERMDISP; Anderson, 2004, 2006) was used to check for variability in the diet between the specimens of $G$. cf. proximus from each sampling area (cage farm and control). By using PERMDISP, the distance from the median (i.e. similar to the centroid) of a group defined a priori is calculated; in this case, the species/sampling area analyzed through a principal coordinate analysis (PCoA). This procedure allows for the verification of homogeneity of an individual diet by comparing the dispersion between and within the groups (Silva et al., 2017). The calculation of the median of the group was performed using the Bray-Curtis dissimilarity measure, which allows the comparison of the average dissimilarity in $n$ individual observations within the group. Subsequently, the niche breadth was measured on the basis of the spatial dispersion of the diets. The test was conducted with a dietary similarity matrix. The assumption was that differences in the distance of the dispersion of the diet between sampling areas (cage farm and control) indicate whether the individuals from each area have more restricted or broader diets. (i.e., a greater distance indicates a broader niche) (Correa and Winemiller, 2014). To test the null hypothesis that the niche breadth did not differ among the groups (fish from the cage farm and control areas), an $\mathrm{F}$ statist was calculated to compare the average distance of each sample to the median of the group. Subsequently, the $p$ value was obtained through 9999 permutations of the residuals of the least squares (Anderson, 2006). Post hoc pairwise comparisons were made by Tukey's Honest Significant Difference method.

Shannon's diversity index (H') was calculated to verify the diversity of food items in each sampling area (cage farm and control) (Pielou, 1975).

To check the nutritional state of an individual at a larger scale, the relative condition factor $(\mathrm{Kn})$ was calculated using the standard length (Ls) and total weight (Wt) in the equation ( $\mathrm{Kn}=\mathrm{Wt} / \mathrm{We})$, where $\mathrm{Wt}$ is the observed individual weight and We is the estimated weight of the individual based on the relationship between standard length and weight (Le Cren, 1951). The relative condition factor is the ideal model for this study because, according to Le Cren (1951), it takes into account the expected weight and the observed weight, minimizing the effects of reproductive or gonad-formation events since the ratio between the observed and expected weight is equal to one (1) under normal conditions. Furthermore, any change in this ratio will cause variations in this calculation. Thus, environmental alterations, lack of food or even parasitism, can affect with the calculation of the relative condition factor. The relative condition factor values were compared between fish from the sampling areas by the Mann-Whitney test ( $U$ test). 
Table 1

Definition of histopathological alterations in the liver observed in Geophagus cf. proximus in the Ilha Solteira Reservoir, Upper Paraná River, Brazil.

\begin{tabular}{|c|c|c|}
\hline Histopathological alteration & Definition & Reference \\
\hline Cytoplasmic vacuolization & $\begin{array}{l}\text { The accumulation of lipids in the vesicles as a cellular response to the presence of lipophilic chemical } \\
\text { agents in an attempt to immobilize these substances and avoid their interaction with the other cellular } \\
\text { components and, thus, minimize their toxic effects. }\end{array}$ & Oliveira Ribeiro et al. (2012) \\
\hline Aggregates of melanomacrophages & $\begin{array}{l}\text { Inflammatory response assisting in the process of eliminating lipids by neutralizing the free radicals } \\
\text { produced by the phagocytosis of polyunsaturated lipids, in addition to the removal of necrotic cells. }\end{array}$ & $\begin{array}{l}\text { Agius and Roberts (2003), Mela } \\
\text { et al. (2007) }\end{array}$ \\
\hline Leukocyte infiltration & $\begin{array}{l}\text { Leucocytes are a sign of inflammation and hypersensitivity. They can penetrate the walls of blood vessels } \\
\text { and infiltrate the surrounding tissue. }\end{array}$ & Bernet et al. (1999) \\
\hline Hyperemia & Sinusoid dilatation characterized by blood congestion with consequent liver hyperemia. & $\begin{array}{l}\text { Bernet et al. (1999), Paulino } \\
\text { et al. (2014) }\end{array}$ \\
\hline Cytoplasmic degeneration & $\begin{array}{l}\text { When hepatocytes are unable to metabolize and mobilize lipid vesicles, cytoplasmic degeneration may } \\
\text { occur. }\end{array}$ & $\begin{array}{l}\text { Lee et al. (2012), Kumar et al. } \\
\text { (2013) }\end{array}$ \\
\hline Vascular congestion & $\begin{array}{l}\text { Obstructions in the blood vessels, promoting their dilation. Circulation velocity decreases at the site of } \\
\text { obstruction, promoting blood accumulation and lesions in epithelial tissue. }\end{array}$ & Roberts (1989), Verlag (1982) \\
\hline Necrosis & Morphological state of a cell or tissue that appears after irrevocable loss of cell function. & Bernet et al. (1999) \\
\hline
\end{tabular}

Histological alterations were quantified in five random microscopic fields/section for five sections/sample. The incidence and distribution of liver lesions (Table 1) were evaluated based on the following criteria: 0 , absent (absence or lesions in up to $10 \%$ of the total tissue analyzed); $0+$, rarely present (lesions in $11 \%-25 \%$ of the analyzed tissue); +, present (lesions in $26 \%-50 \%$ of the analyzed tissue); ++ , frequent (lesions in $51 \%-75 \%$ of the analyzed tissue) and +++ , very frequent (lesions in $76 \%-100 \%$ of the analyzed tissue) (Paulino et al., 2014).

The presence of histological alterations in the liver was evaluated semi-quantitatively by the histopathological index of the liver $\left(\mathrm{HI}_{\mathrm{L}}\right)$ based on the severity of the lesions, calculated according to Camargo and Martinez (2007) and as modified from Poleksic and MitrovicTutundzic (1994). The alterations were classified into progressive stages in the tissue as follows: stage I, which do not alter the normal functioning of the tissue; stage II, which are more severe and interfere with tissue functioning; and stage III, which are very severe and cause irreparable damage. The $\mathrm{HI}_{\mathrm{L}}$ was calculated from the sum of the types of lesion for each of the three stages and multiplied by the stage index using the following equation proposed by Poleksic and MitrovicTutundzic (1994):

$\mathrm{IH}=10^{0} \sum_{\mathrm{i}=1}^{\mathrm{a}} a i+10^{1} \sum_{\mathrm{i}=1}^{\mathrm{b}} b i+10^{2} \sum_{\mathrm{i}=1}^{\mathrm{c}} c i$

in which $\mathrm{a}=$ first stage alterations $(\mathrm{SI}), \mathrm{b}=$ second stage alterations (SII) and $\mathrm{c}=$ third stage alterations (SIII). $\mathrm{HI}_{\mathrm{L}}$ values between 0 and 10 indicate a normal function of the organ; values between 11 and 20 indicate mild to moderate damage; values between 21 and 50 indicate moderate to severe damage; values between 51 and 100 indicate severe damage; and values above 100 indicate irreversible damage (Poleksic and Mitrovic-Tutundzic, 1994).

The mean alteration value of the liver $\left(\mathrm{MAV}_{\mathrm{L}}\right)$ for each specimen was calculated according to Schwaiger et al. (1997) and as modified by Paulino et al. (2014) using the following numerical values: $0-1$, no pathological alterations; $1.1-2$, focal mild alterations; $2.1-3$, moderate spread of lesions; 3.1-4, frequent lesions; and 4.1-5, widely distributed lesions.

To quantify the level of hepatic steatosis (HS), a scale based on the classification of Brunt (2001) and adapted for fish was used. Thus, HS ranges from 0 to 3 , where 0 indicates that less than $5 \%$ of hepatocytes are affected; 1 , that from 5 to $30 \%$ are affected; 2 , that from 30 to $60 \%$ are affected; and 3 , that more than $60 \%$ are affected.

Possible differences in $\mathrm{HI}_{\mathrm{L}}, \mathrm{MAV}_{\mathrm{L}}$ and total protein concentrations between fish from the sampling areas were tested using a Student's $t$ test.

The protein concentrations for livers and gonads were compared between fish from the sampling areas by the Mann-Whitney test ( $U$ test).

PERMANOVA and PERMDISP were run using the R programming environment, with the help of the Vegan package ( $R$ Development Core Team, 2015). For Student's t-tests, SigmaStat 3.1 (Jandel Scientific, USA) was used. SIMPER, $H^{\prime}$ and the $U$ test analyses were run using PAST version 2.16 (Paleontological Statistics Software) (Hammer et al., 2001). For all statistical analyses, a value of $p<0.05$ was adopted as the threshold for significance.

\section{Results}

\subsection{Diet and relative condition factor}

For the analysis of stomach contents, a total of $31 \mathrm{G}$. cf. proximus individuals from the control area and 32 individuals from the cage farm area were used. The standard lengths of the fish ranged from 8 to $15 \mathrm{~cm}$, and there was not a significant difference between fish from the two sites $(\mathrm{z}=-1.9177, \mathrm{p}=0.055)$. Geophagus $\mathrm{cf}$. proximus consumed items from varied sources and origins, indicating an omnivorous diet. The main items ingested in the control area were detritus, aquatic plants and Cladocera, while Bivalvia, pelleted feed and detritus were the most representative of the diet of specimens from the cage farm area (Table 2).

Significant differences in diet composition were found between areas (PERMANOVA, DF $=1 ; \mathrm{F}=6.09, \mathrm{p}=0.0001$ ). According to the SIMPER analysis, detritus, Bivalvia and pelleted feed were the items that contributed most to the differentiation of the diet between the cage farm and control areas. Bivalvia and pelleted feed were more abundant in the cage farm area, and detritus was more common in the control area. It should be noted that pelleted feed was only present in the diet of fish from the cage farm area (Table 3).

The average trophic niche breadth was highest for individuals in the cage farm area (Fig. 2). However, the dietary variability among the specimens was lower, that is, they concentrated their diet on a few items, especially pelleted feed and Bivalvia. Fish from the control area exhibited a lower trophic niche breadth (Fig. 2) and greater dietary variability among the specimens. The average trophic niche breadth differed significantly between the sampling areas (PERMDISP, DF $=1$; $\mathrm{F}=5.73, \mathrm{p}=0.03$ ).

The Shannon's diversity index for the food items consumed in both areas showed higher values for the control area ( $\left.H^{\prime}-2.24\right)$ in relation to the cage farm area ( $\left.\mathrm{H}^{\prime}-1.8\right)$, correlating with the greater variability of food items in the control area (Fig. 2).

All individuals captured (Table 2) were used to verify nutritional statuses at both sites. It is worth mentioning that as many adults as possible were used in order to reduce the effects of size classes. No significant differences were detected in the relative condition factor between the sampling areas $(z=-0.62296 ; \mathrm{p}=0.53)$. 
Table 2

Food items consumed by Geophagus cf. proximus in the Ilha Solteira Reservoir, Upper Paraná River, Brazil. Values are based on percentage data for the volumes of food items. Bold values represent items that contributed most to the diet of the species between the sampling sites.

\begin{tabular}{|c|c|c|}
\hline Local & Control & Cage farm \\
\hline Abundance & 76 & 40 \\
\hline Stomach numbers & 31 & 28 \\
\hline Length class ranges & $8-15 \mathrm{~cm}$ & $8-15 \mathrm{~cm}$ \\
\hline Food item & Volume (\%) & Volume (\%) \\
\hline Bacillariophyceae & 0.09 & \\
\hline Cloroficeae & 0.44 & \\
\hline Chordariaceae & 0.04 & \\
\hline Aquatic plants & 9.72 & 1.67 \\
\hline Copepod & 0.18 & \\
\hline Cladocera & 7.14 & \\
\hline Ostracods & 0.61 & \\
\hline Bivalvia & 3.53 & 25.61 \\
\hline Gastropoda & 3.58 & 14.07 \\
\hline Mollusca & 0.04 & \\
\hline Scales & 9.56 & 3.79 \\
\hline Diptera larvae & 6.22 & 1.00 \\
\hline Diptera pupa & 0.05 & 0.15 \\
\hline Ephemeroptera & 0.58 & \\
\hline Trichoptera & 0.05 & \\
\hline Plecoptera & 0.02 & \\
\hline Odonata & 3.64 & \\
\hline Remains of aquatic insects & 8.58 & 0.58 \\
\hline Terrestrial plants & 9.86 & 9.09 \\
\hline Diptera adults & 0.01 & \\
\hline Aranae & 0.02 & \\
\hline Acari & 4.30 & \\
\hline Remains of terrestrial insects & 0.22 & 0.19 \\
\hline Detritus & 31.53 & 20.67 \\
\hline Pelleted feed & & 23.20 \\
\hline
\end{tabular}

Table 3

Results of the dissimilarity analysis (SIMPER) for the proportion of food items found in Geophagus cf. proximus between the sampling areas in the Ilha Solteira Reservoir, Upper Paraná River, Brazil.

\begin{tabular}{|c|c|c|c|c|c|}
\hline \multirow[t]{2}{*}{ Food item } & \multirow{2}{*}{$\begin{array}{l}\text { Overall } \\
\text { average } \\
\text { dissimilarity }\end{array}$} & \multirow[t]{2}{*}{ Contribution $\%$} & \multirow{2}{*}{$\begin{array}{l}\text { Cumulative } \\
\text { contribution } \\
\%\end{array}$} & \multicolumn{2}{|c|}{ Mean abundance } \\
\hline & & & & Control & Cage farm \\
\hline Detritus & 83.7 & 25.8 & 25.8 & 0.0258 & 0.0163 \\
\hline Bivalvia & & 20.8 & 46.6 & 0.0054 & 0.0345 \\
\hline $\begin{array}{r}\text { Pelleted } \\
\text { feed }\end{array}$ & & 17.7 & 64.3 & 0.0 & 0.0202 \\
\hline $\begin{array}{l}\text { Aquatic } \\
\text { plants }\end{array}$ & & 8.0 & 72.3 & 0.007 & 0.001 \\
\hline $\begin{array}{r}\text { Terrestrial } \\
\text { plants }\end{array}$ & & 6.7 & 79.0 & 0.001 & 0.007 \\
\hline
\end{tabular}

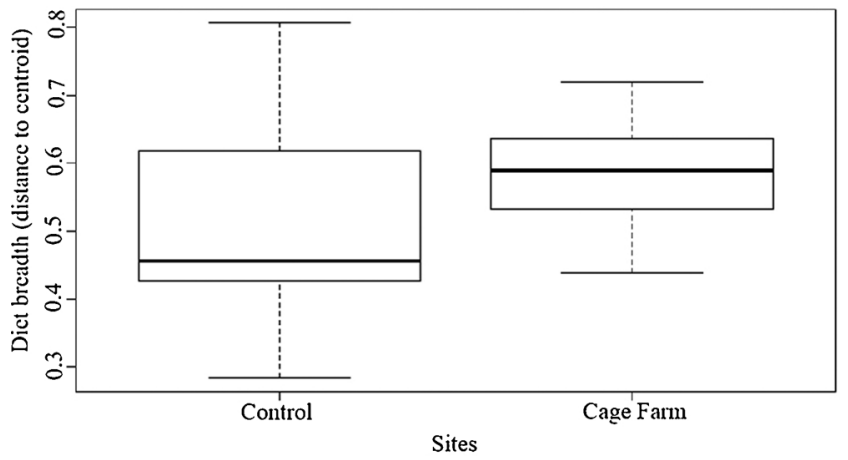

Fig. 2. Variation in the dietary breadth of Geophagus cf. proximus assessed using PERMDISP for the sampling areas (control and cage farm) in the Ilha Solteira Reservoir, Upper Paraná River, Brazil. Boxes show the lower and upper endpoints, representing the 25th and 75th quartiles, respectively, and demonstrate the individual variability of the diet. The horizontal bar within each box represents the average dietary.

\subsection{Histopathological alterations in the liver}

The hepatic parenchyma of $G$. cf. proximus showed hepatocytes with a central nucleus, prominent nucleoli and homogeneous cytoplasm, as well as diffuse pancreatic tissue. This organ is called the hepatopancreas (Fig. 3A and B). The liver of fish from the cage farm area presented alterations, such as hyperemia, severe vascular congestion, cytoplasmic degeneration, an absence of nuclei, and foci of necrosis (Fig. 3C-H). Mild alterations such as leukocyte infiltration (Fig. 3F), aggregates of melanomacrophages (Fig. 3G) and cytoplasmic vacuolization (Fig. $3 \mathrm{H}$ ) were observed in fish from both sampling areas. No hypertrophic nuclei, nuclei in lateral positions or pyknotic nuclei were observed in any of the specimens.

The livers of fish sampled from both areas presented low frequencies of histopathological alterations (Table 4). However, it was observed through the $\mathrm{HI}_{\mathrm{L}}$ and $M A V_{\mathrm{L}}$ indices, that the histopathological alteration of the specimens from the cage farm area was more severe, with a higher frequency and irreparable lesions, compared to those in fish from the control area (Table 4). In addition, intense pancreatic hyperplasia and the presence of intrahepatic adipocytes were identified in hepatopancreas from fish from the cage farm area (Fig. 4A-D). In the cage farm group, $83.4 \%$ grade 2 steatosis and $16.6 \%$ had grade 3 steatosis, while in the control group, $66.6 \%$ had grade 0 steatosis and $33.3 \%$ had grade 1 steatosis.

\subsection{Metabolic physiology}

There was no statistical difference in total protein concentrations in muscle tissues between fish from the evaluated areas $(t=0.804$; $\mathrm{p}=0.455)$. However, hepatic and gonadal tissues presented significant differences in concentrations between fish from the two areas. Higher concentrations of hepatic proteins were found in fish from the cage farm area $(t=17 ; \mathrm{p}=0.032)$, while higher concentrations of gonadal proteins were found in fish from the control area $(t=39 ; \mathrm{p}=0.016)$ (Fig. 5).

\section{Discussion}

The high consumption of pelleted feed by $G$. cf. proximus in the area under the influence of the cage fish farm showed the interference from this cultivation system in the trophic ecology of this wild species. In addition to the consumption of pelleted feed, the important contribution of Bivalvia and Gastropoda as food sources of $G$. cf. proximus in the cage farm area was demonstrated. The abundance of these items is related to local organic enrichment, which can occur due to the constant input of organic matter. This input attracts filter-feeding invertebrates and detritivores, such as Bivalvia and Gastropoda (Nabirye et al., 2016).

Although fish are generally flexible in their diets (Gerking, 1994; Abelha and Goulart, 2004), drastic changes in the availability and supply of resources particularly affect more generalist and omnivorous species, as in the case of $G$. cf. proximus. Thus, considering that individuals will consume the most available food items, in this case feed pellets and mollusks, it can be inferred that the change in diet will cause changes at other levels of the food chain. This pattern of interference by cage fish farms on freshwater ecosystems has also been reported for other omnivorous species, such as Metynnis maculatus (Ramos et al., 2008; Demétrio et al., 2012), Pimelodus maculatus, Astyanax lacustris (=Astyanax altiparanae) (Ramos et al., 2013) and Apareiodon affinis (Brandão et al., 2012). This pattern is also reported in the marine environment for the wild species Boops boops (Fernandez-Jover et al., 2008; Arechavala-Lopez et al., 2011), Trachurus mediterraneus (Fernandez-Jover et al., 2007; Fernandez-Jover et al., 2008), Sardinella aurita and Trachinotus ovatus (Fernandez-Jover et al., 2008).

It is worth mentioning that although the process of damming environments constitutes an undeniable source of ecological impacts 

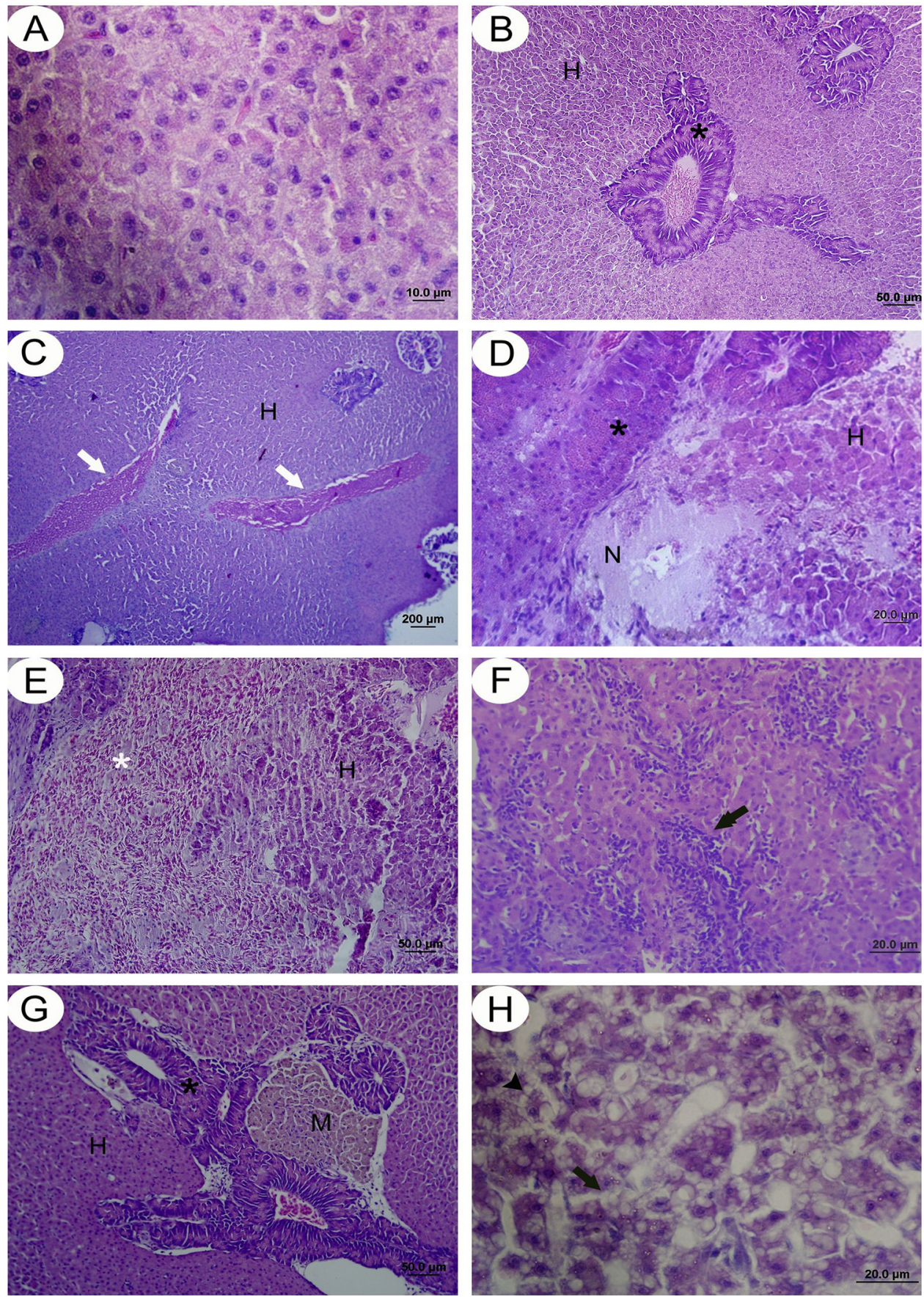

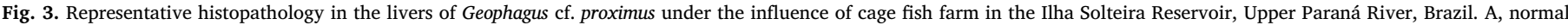

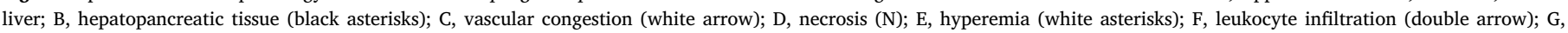

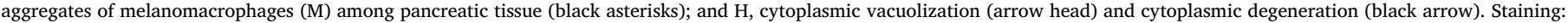
Harris hematoxylin and eosin. Scale bar is in $\mu \mathrm{m}$.

(Agostinho et al., 2007) that can alter the trophic structure (Hahn and Fugi, 2007; Delariva et al., 2013), cage fish farm systems are additional and direct sources of organic matter in these systems. This hypothesis gains support since the current results demonstrate a clear difference in the diet composition of the species between an area under the influence of cage fish farm and an area free from this influence. The consumption mainly of items of autochthonous origin, such as detritus, aquatic plants and Cladocera in the control area and of pelleted feed and Bivalvia in the cage farm area indicate that the easy acquisition and high availability of nutrients from the cage fish farm substantially affected the trophic ecology of the evaluated species, following the theory of optimal foraging (Gerking, 1994).
Tropical rivers have large amounts of detritus and sediment due to a climatic regime with high temperatures and intense rainfall events (Bowen, 1984; Ibañez et al., 2009). This detritus consists of the remains of plants, animals and organisms associated, for the most part, with particles of inorganic sediment. In this sense, the high occurrence of detritus in tropical rivers may explain its important contribution to the diet of fish, both in the control area and in the cage farm area. Moreover, the higher sedimentation rate in cage farm areas contributes to the formation of deposits of this material on the bottom and to their increased availability to fish (Brandão et al., 2012; Ramos et al., 2013; Edwards, 2015). In addition, the benthic habit, as well as the protractile and terminal mouth of the species studied herein, favors the 
Table 4

Histopathological alterations in the livers of Geophagus cf. proximus from the sampling areas (control and cage farm) in the Ilha Solteira Reservoir, Upper Paraná River, Brazil; scores: 0 (0-10\%); $0+(11-25 \%) ;+(26-50 \%) ;++(51-75 \%) ;+++(76-100 \%)$. Mean alteration values (MAVs) and the histopathological index (HI) of the liver (L) for Geophagus cf. proximus. Index values are expressed as the mean \pm SEM ( $\mathrm{n}=8$ animals/ group). Student's $t$-test; ${ }^{*} \mathrm{p} \ll 0.001$. • indicates a value equal to zero.

\begin{tabular}{|c|c|c|c|}
\hline \multirow[t]{2}{*}{ Histopathological alterations } & \multirow[t]{2}{*}{ Stage } & \multicolumn{2}{|l|}{ Local } \\
\hline & & Control & Cage farm \\
\hline Hypertrophic nuclei & I & $0 \cdot$ & $0 \cdot$ \\
\hline Nuclei in lateral position & I & $0 \cdot$ & $0 \cdot$ \\
\hline Cytoplasmic vacuolization & I & $0(5.56 \pm 5.58)$ & $0+(9.55 \pm 8.18)$ \\
\hline Aggregates of melanomacrophages & I & $0(0.5 \pm 0.4)$ & $0(3 \pm 0.34)$ \\
\hline Leukocyte infiltration & I & $0 \cdot$ & $0(1.91 \pm 1.73)$ \\
\hline Hyperemia & I & $0 \cdot$ & $0(5.6 \pm 1.38)$ \\
\hline Cytoplasmic degeneration & II & $0 \cdot$ & $0(2.2 \pm 2.24)$ \\
\hline Vascular congestion & II & $0 \cdot$ & $0(1.2 \pm 0.79)$ \\
\hline Pyknotic nuclei & II & $0 \cdot$ & $0 \cdot$ \\
\hline Nucleus absence & II & $0 \cdot$ & $0(1.1 \pm 1.07)$ \\
\hline Necrosis & III & $0 \cdot$ & $0(6.2 \pm 1.47)$ \\
\hline
\end{tabular}

\begin{tabular}{lll} 
Histopathological Index & \multicolumn{2}{l}{ Local } \\
\cline { 2 - 3 } & Control & Cage farm \\
\hline Histopathological Alteration Index $\left(\mathrm{HI}_{\mathrm{L}}\right)$ & $1.75 \pm 1.22$ & $117.3 \pm 2.09^{*}$ \\
Mean alteration values $\left(\mathrm{MAV}_{\mathrm{L}}\right)$ & $1.50 \pm 0.34$ & $3.83 \pm 0.47^{*}$ \\
\hline
\end{tabular}

consumption of food near the substrate (Gerking, 1994; Castro et al., 2004; Graça and Pavanelli, 2007). The consumption of detritus was also reported by Moretto et al. (2008), demonstrating that this food item is frequently consumed by $G$. cf. proximus. Furthermore, herbivorous (Silva et al., 2005) and insectivorous (Vidotto and Carvalho, 2009) habits were also described, which suggests that the species can change its feeding habit according to the availability of resources and environmental conditions.

Species of the genus Geophagus have been used as indicators of negative impacts on aquatic ecosystems, especially rivers with little or no riparian vegetation and anthropically altered environments, since their tolerance to hypoxia and their generalist habit (Caetano et al., 2016; Cetra and Ferreira, 2016; Morais et al., 2016; Gomes et al., 2016), favor colonization in these environments. In this way, if they have available food, these individuals can perform other essential activities, such as growth and reproduction.

The opportunistic and omnivorous habit of $G$. cf. proximus favors the consumption of pelleted feed, which is highly available in areas of cage fish farm, as demonstrated in the results of this work. Pelleted feed contains ingredients that, while favoring a positive energy balance (Edwards, 2015), can cause serious problems in the tissues and organs of the fish and thus affect the individual's fitness, with severe consequences for the long-term survival of the individual (Takashima and Hibiya, 1995; Fernandez-Jover et al., 2007). Positive energy balance has been reported for fish species from both marine (Fernandez-Jover et al., 2007; Fernandez-Jover et al., 2008; Arechavala-Lopez et al., 2011) and freshwater environments (Brandão et al., 2012; Ramos et al., 2013), with the highest condition factor for the individuals sampled in the vicinity of the cage fish farms, as a result of the feed intake. However, in this study, the results of the relative condition factor did not demonstrate influence of cage fish farm on the current nutritional condition.

Nevertheless, histopathological alterations in the livers of the specimens from the cage farm area were found. Hepatic steatosis was also observed only in fish from the cage farm area. Thus, it is inferred that these alterations could have been triggered by the greater consumption of Mollusca (Bivalvia and Gastropoda) and pelleted feed in the cage farm area. Mollusca in its integral form (valves and body content) has a crude protein content of 12.95\% (Canzi, 2011), and pelleted feed has high levels of proteins and lipids that can promote rapid growth and fat accumulation, as well as modification in fatty acid patterns (FernandezJover et al., 2007; Fernandez-Jover et al., 2008; Arechavala-Lopez et al., 2011). Studies have demonstrated a relationship of histopathological changes with the consumption of a diet containing high protein and lipid levels for both freshwater (Liu et al., 2016; Zhang et al., 2017) and marine cultured fish species (Ségade et al., 2015; Piaoping et al., 2016), corroborating the results of this work. In addition, for marine environment abnormal levels of the hepatic index associated to feed consumption were observed (Fernandez-Jover et al., 2007).
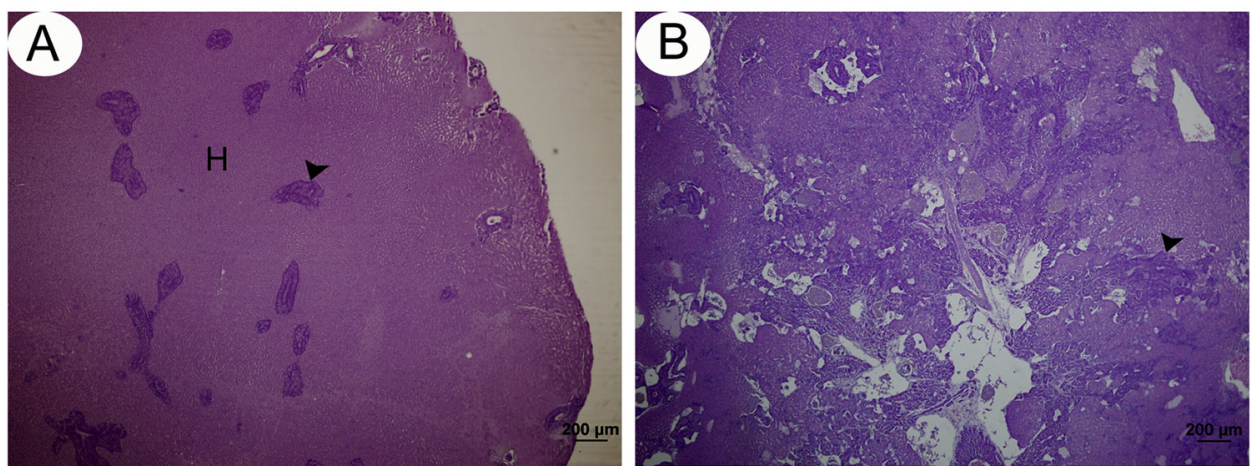

Fig. 4. Photomicrograph of livers of Geophagus cf. proximus under the influence of cage fish farm in the Ilha Solteira Reservoir, Upper Paraná River, Brazil. A - Normal hepatopancreas - diffuse pancreatic tissue (arrow) in hepatic tissue $(\mathrm{H})$; B, pancreatic hyperplasia (arrow head); C, intrahepatic adipocytes (arrow); and D, adipose tissue associated with hepatopancreas (*). Staining: Harris hematoxylin and eosin. Scale bar is in $\mu \mathrm{m}$.
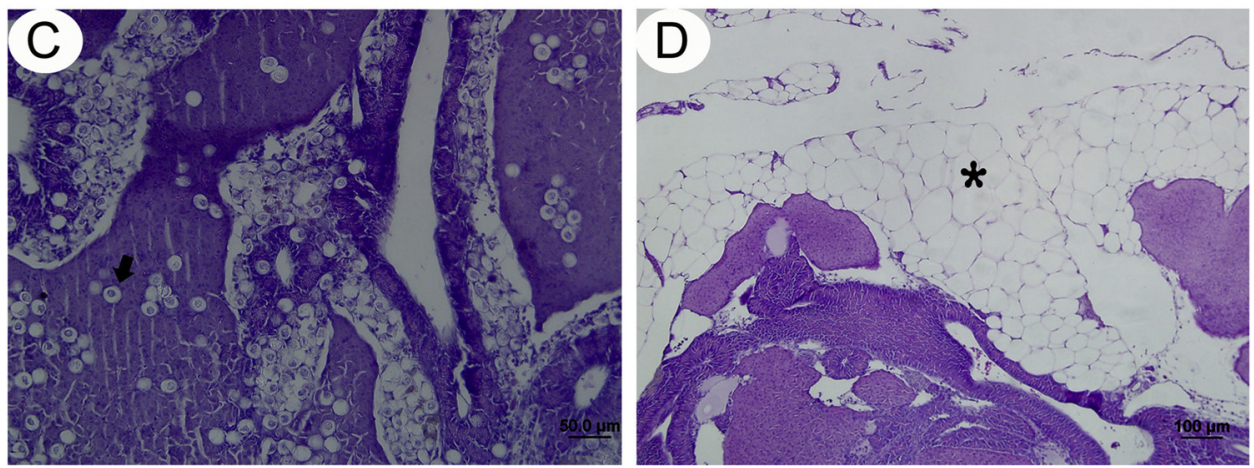

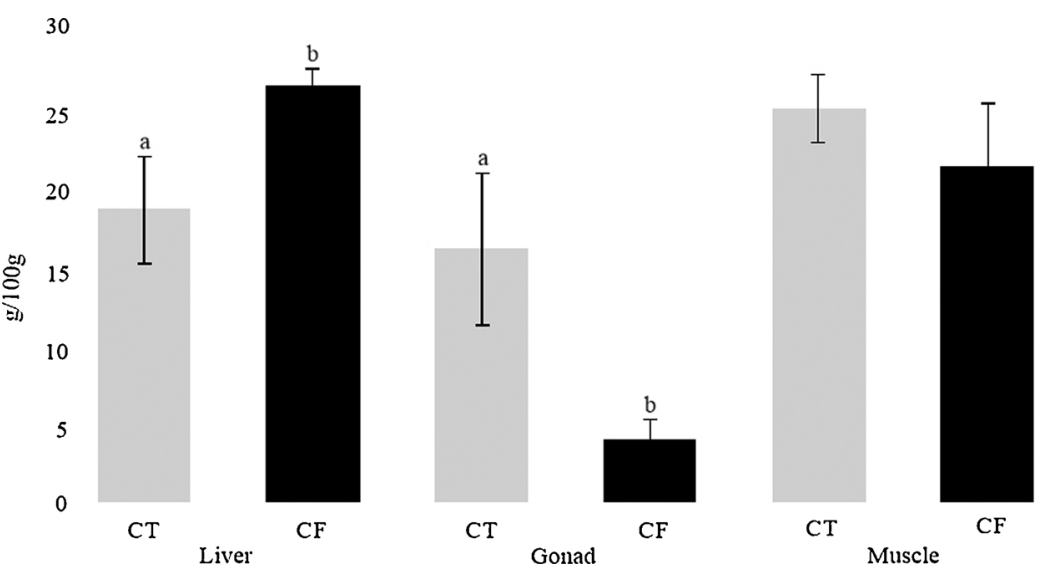

Fig. 5. Concentrations of total hepatic, gonadal and muscle proteins ( $\mathrm{g}$ / $100 \mathrm{~g}$ ) in Geophagus cf. proximus for the sampling areas (control (CT) and cage farm (CF)), in the Ilha Solteira Reservoir, Upper Paraná River, Brazil. Data are expressed as the mean \pm standard error. Different letters $(a, b)$ indicate statistically significant differences for each organ between the experimental groups sampled.
Lipids can be found in adipocytes associated with the hepatopancreas in the form of intrahepatic adipocytes or as small droplets interspersed with cell organelles (cytoplasmic vacuolization) (Takashima and Hibiya, 1995; Yancheva et al., 2016). In this study, the presence of the three forms of lipid deposition reported in the literature was verified, which are considered frequent in fish associated with cage fish farm due to the high concentration of proteins and lipids in pelleted feed (Takashima and Hibiya, 1995). Studies of Mediterranean coastal fish farms demonstrated higher muscle fat content and modification in fatty acid patterns in farm-associated fishes (Fernandez-Jover et al., 2007; Arechavala-Lopez et al., 2011; Ségade et al., 2015). Thus, it is observed that modifications in metabolic aspects due to pelleted feed consumption occur in both freshwater and marine environments. It is important to emphasize that excess protein in the liver is stored as lipids after the deamination of amino acids, and these lipids will be used as an energy source, which causes an overload in liver function (Hepher, 1989; Almeida et al., 2011). This metabolic pathway may also have contributed to the steatosis verified in the livers of fish from the cage farm area.

Thus, a cascade of alterations triggered by hepatic steatosis may have caused functional and structural damage to the livers in the fish analyzed. In an initial process, when the liver stores lipids in the form of vacuoles, cytoplasmic vacuolization occurs. Subsequently, when it is unable to metabolize and mobilize them, cytoplasmic degeneration may occur (Lee et al., 2012). In a more advanced stage, cytoplasmic degeneration can promote damage to membrane integrity and extravasation of the cellular contents, leading to an inflammatory response through the action of lysosomal enzymes (Stentiford et al., 2003; Lee et al., 2012; Kumar et al., 2013, Yancheva et al., 2016). Lysosomes enter the cytoplasm and digest the cell, resulting in necrosis (Kumar et al., 2013). Necrosis was the most severe alteration observed in $G$. cf. proximus livers and was more frequent in fish from the cage farm area than in the control area. Studies have shown that nutritional imbalances, such as a diet containing high protein concentrations, can lead to cellular lesions (Kumar et al., 2013) and disorders in protein synthesis and carbohydrate metabolism (Mela et al., 2007; Yancheva et al., 2016).

Lesions and inflammations due to cytoplasmic vacuolization, cytoplasmic degeneration and necrosis explain the presence of the histopathological alterations observed in the livers of fish from the cage farm area, including melanomacrophage aggregates, leukocyte infiltration, hyperemia and vascular congestion. Melanomacrophage aggregates assist in eliminating lipids by neutralizing the free radicals produced by the phagocytosis of polyunsaturated lipids, in addition to the removal of necrotic cells (Agius and Roberts, 2003; Mela et al., 2007). Leukocyte infiltration is a sign of inflammation and hypersensitivity (Tripathi and Srivastav, 2010). Hyperemia suggests increased blood flow in the liver tissue, which helps in the transportation of macrophages to the damaged areas and in the oxygenation of these areas. These factors may be related to metabolic detoxification that occurs in fish. In more severe cases, hyperemia may lead to hepatic necrosis and atrophy (Yancheva et al., 2016). Vascular congestion can be caused by obstructions in the blood vessels, promoting their dilation. Circulation velocity decreases at the site of obstruction, promoting blood accumulation and lesions in epithelial tissues (Verlag, 1982; Roberts, 1989). Epithelial cell damage can affect the exchange between hepatocytes and sinusoid vessels (e.g. the distribution of nutrients, chemical signals or other physiological components) and thus compromise the stability of organic functions (Yancheva et al., 2016).

Another alteration found in the livers of fish from the cage farm area was the greater proportion of pancreatic tissue. Pancreatic tissue secretes trypsin and exopeptidases to aid in protein digestion (Randall et al., 2000; Baldisserotto, 2013). In addition, it aids in the digestion of lipids by secreting lipase, an enzyme that, with the help of bile acids secreted by the liver, cleaves fat molecules (Schmidt-Nielsen, 1999). In this context, the greater proportion of pancreatic tissue found in specimens from the cage farm area can be explained by the high intake of proteins and lipids associated with a diet with high proportions of pelleted feed and Bivalvia.

The histopathological alterations observed in livers of fish from the cage farm area may have affected hepatic function, with effects on the metabolism of the animal. Thus, it can be inferred that impaired liver function influenced specific metabolic responses in this tissue, resulting in a higher concentration of proteins in comparison with levels in specimens collected in the control area as a result of diet modification, which ultimately caused histopathological changes in these specimens. Several studies have reported that changes in diet alter the hepatic protein content and may result in histopathological changes, such as studies on Oreochromis (Chen et al., 2009; Honorato et al., 2014; Ning et al., 2017), a species belonging to the same family as $G$. cf. proximus.

In addition to the reported changes in hepatic protein concentration, the concentration of gonadal proteins was lower in fish from the cage farm area than in the specimens from the control area. There is a possibility of hepatic dysregulation affecting the deposition of proteins in different organs in $G$. cf. proximus since it engages in split spawning throughout the year (Branco et al., 2012). The gonads in fish from both sampling areas should contain high levels of proteins due to the production of vitellogenin. During vitellogenesis, the liver mobilizes proteins and lipids from hepatic tissue that are used in the production of vitellogenin and that make up the contents of oocytes (Sumpter et al., 1984; Babin and Vernier, 1989; Tyler et al., 1990; Tiwary et al., 2002). In view of this, the hepatic steatosis and histopathological changes observed in the livers of $G$. cf. proximus in this study could be responsible for the differences found in the concentration of proteins in the livers and gonads of the individuals in the cage farm area.

Once liver functions are impaired, the liver tissue would not be able to properly mobilize the proteins needed by the gonads. However, the analyses conducted in this study, using a single sampling, are not 
enough to affirm this possible interference with vitellogenesis. Studies have reported effects on the reproduction of wild species due to the introduction of manure into the environment resulting from fish farms in marine cage farms (Uglem et al., 2014). Nevertheless, these authors failed to explain the mechanisms underlying these effects.

Despite being considered a very plastic tissue (Bombardier et al., 2010) and responsive to dietary changes and environmental influences (Bureau et al., 2000), muscle tissue did not demonstrate differences between the specimens collected in the control and cage farm areas in this study, in contrast to the changes seen in hepatic and gonadal tissues.

Considering the results presented here, questions about the influence of fish farm on the residence time of $G$. cf. proximus in the vicinity of the cages or on their migration between the control and cage areas can be raised. However, this species does not perform a reproductive migration and has a limited ability to swim long distances because it has fusiform body and wide fins that allow for high maneuverability but limit swimming efficiency (Oliveira et al., 2010). Thus, they are able to explore the various compartments of the river channel, from the bottom to the surface, but have little ability to migrate through open water, thus reducing the possibility of migrating for $10 \mathrm{~km}$ between the control and cage farm areas. In this sense, the results presented confirm an influence of this rearing system on the feeding of this species.

There are also papers that discuss the biofiltering role of wild fish associated with cage farms that reduces the impact of organic matter input (Felsing et al., 2005; Fernandez-Jover et al., 2008). In terms of the removal of the organic matter by fishes, this biofiltering role is advantageous for the environment. However, taking into account the changes affecting the liver and gonads of the species studied here, it can be inferred that in the long term, trophic relationships in the whole community can be affected, thus causing an imbalance in this ecosystem.

\section{Conclusions}

In summary, the presence of a cage fish farm caused changes in the diet composition of the wild species $G$. cf. proximus, which exhibited a high consumption of pelleted feed. The diet contained high lipid and protein concentrations did not alter the relative condition factors of the specimens. However, it promoted severe histopathological alterations in the liver, impairing hepatic functions, including possibly interfering with gonadal metabolism. Once $G$. cf. proximus presents a high economic value and is used by the fishermen for commercial purposes, information about impacts on its biology, along with possible interference in its long-term population dynamics, will be of extreme importance.

\section{Funding}

This work was supported by the CNPq (grant number 443103/20143 / and 457083/2014-0 and scholarship of the 1st author grant 132454/ 2016-5) and FUNDUNESP/PROPE UNESP (grant number 0305/001/ 14-PROPe/CDC) for providing financial support.

\section{Authors contribution}

Conceived and designed the experiments: Bruna Caroline Kotz Kliemann, Rosilene Luciana Delariva and Igor Paiva Ramos (Teacher advisor). Collected specimens: Igor Paiva Ramos. Performed the experiments: Bruna Caroline Kotz Kliemann, Bruno da Silva, Cristiéle da Silva Ribeiro and Igor Paiva Ramos. Analyzed the data: Bruna Caroline Kotz Kliemann, Bruno da Silva, Cristiéle da Silva Ribeiro, Rosilene Luciana Delariva, João Paulo de Arruda Amorim and Igor Paiva Ramos. Wrote the paper: Bruna Caroline Kotz Kliemann' Rosilene Luciana Delariva, João Paulo de Arruda Amorim, Cristiéle da Silva Ribeiro, Igor Paiva Ramos and Rosicleire Verissimo Silveira.

\section{Acknowledgements}

UNESP and UNIOESTE for providing physical facilities.

\section{References}

Abelha, M.C.F., Goulart, E., 2004. Oportunismo trófico de Geophagus brasiliensis (Quoy \& Gaimard, 1824) (Osteichthyes, Cichlidae) no reservatório de Capivari, Estado do Paraná, Brasil. Acta Sci. Biol. Sci. 26, 37-45.

Abrahão, D.S., Toledo Piza, A.R., Martins, M.D.A., Silva Neto, J.C., Ferreira, E.C., Rapado, L.N., Pires, M.D.F.C., 2004. Estudo comparativo com diversos fixadores para aplicação em microscopia eletrônica de transmissão. Rev. Inst. Adolfo Lutz 248-254.

Abrunhosa, F., 2011. Técnico em Aquicultura: Piscicultura. IFPA e UFRN, Pará.

Agius, C., Roberts, R.J., 2003. Melano-macrophage centers and their role in fish pathology. J. Fish Dis. 26, 499-509.

Agostinho, A.A., Gomes, L.C., Pelicice, F.M., 2007. Ecologia e manejo de recursos pesqueiros em reservatórios do Brasil. EDUEM, Maringá.

Almeida, L.C., Avilez, I.M., Honorato, C.A., Moraes, G., 2011. Gowth and metabolic responses of tambaqui (Colossoma macropomum) fed diets level of protein and lipid. Aquacult. Nutr. 17, 253-262.

Anderson, M.J., 2001. A new method for non-parametric multivariate analysis of variance. Austral Ecol. 26, 32-46.

Anderson, M.J., 2004. PERMDISP: a FORTRAN Computer Program for Permutational Analysis of Multivariate Dispersions (for Any Two-factor ANOVA Design) Using Permutation Tests. Department of Statistics, University of Auckland.

Anderson, M.J., 2006. Distance based tests for homogeneity of multivariate dispersions Biometrics 62, 245-253.

Arechavala-Lopez, P., Sanchez-Jerez, P., Bayle-Sempere, J., Fernandez-Jover, D., Martinez-Rubio, L., Lopez-Jimenez, J.A., Martinez-Lopez, F.J., 2011. Direct interaction between wild fish aggregations at fish farms and fisheries activity at fishing grounds: a case study with Boops boops. Aquacult. Res. 42, 996-1010.

Babin, P.J., Vernier, J.M., 1989. Plasma lipoproteins in fish. J. Lipid Res. 30, 467-489.

Baldisserotto, B., Cyrino, J.E.P., Urbinati, E.C., 2014. Biologia e fisiologia de peixes neotropicais de água doce. FUNESP, Jaboticabal.

Baldisserotto, B., 2013. Fisiologia de peixes aplicada à piscicultura. UFSM, Santa Maria.

Bernet, D., Schimidt, H., Meier, W., Burkhardt-Holm, P., Wahli, T., 1999. Histopathology in fish: proposal for a protocol to assess aquatic polution. J. Fish Dis. 22, 25-34.

Bicudo, C.E.M., Bicudo, R.M.T., 1970. Algas de águas continentais brasileiras chave ilustrada para identificação de gêneros. Fundação Brasileira para o Desenvolvimento do Ensino de Ciências, São Paulo.

Bombardier, E., Booth, R.K., Green, H.J., Mckinley, R.S., 2010. Metabolic adaptations of oxidative muscle during spawning migration in the Atlantic salmon Salmo salar $\mathrm{L}$. Fish Physiol. Biochem. 36, 355.

Borges, A.M., 2014. Aquicultura Desenvolvimento Sustentável - cenário brasileiro. http://fenacam.com.br/pdf/fenacam2014/aquicultura/4-aquiculturadesenvolvimento-sustentavel-cenario-do-brasileiro_adalmyr-borges.pdf (acesso 15 September 2016).

Bowen, S.H., 1984. Detritivory in neotropical fish communities. In: Zaret, T.M. (Ed.), Evolutionary Ecology of Neotropical Freshwater Fishes. Dr. W. Junk, The Netherlands pp. 173.

Branco, G.S., Silva, A.P.S., Silva, L. M. de J., Ninhaus-Silveira, A., Veríssimo-Silveira, R., 2012. Descrição da hipófise de Geophagus proximus (TELEOSTEI:PERCIFORMES: CICHLIDAE) a partir de análises histológicas e histoquímicas. (Available at:) http:// www.feis.unesp.br/Home/Eventos/encivi/viencivi-2012/branco_hipofise geophagus_58_final.pdf (Acess 11 April 2016).

Brandão, H., Lobón-Cerviá, J., Ramos, I.P., Souto, A.C., Nobile, A.B., Zica, E.O.P., Carvalho, E.D., 2012. Influence of a cage farming on the population of the fish species Apareiodon affinis (Steindachner, 1879) in the Chavantes reservoir, Paranapanema River SP/PR, Brazil. Acta Limnol. Bras. 24, 438-448.

Brandão, H., Nobile b, A., Souto, A.C., Ramos, I.P., Sousa, J.Q., Carvalho, E.D., 2013. Influence of cage fish farming on the diet and biological attributes of Galeocharax knerii in the Chavantes reservoir, Brazil. Bol. Inst. Pesca 39, 157-167.

Brandão, H., Oliveira, J.C.S., Ramos, I.P., Carvalho, E.D., 2014. Influence of cage farming on feeding and reproductive aspects of Pimelodus maculatus Lacépède, 1803

(Siluriformes: Pimelodidae) in the Chavantes reservoir, Brazil. Acta Sci. Biol. Sci. 36 (1), 41-50.

Brunt, E.M., 2001. Nonalcoholic steatohepatitis: definition and pathology. Semin. Liver Dis. $21,3-16$

Bureau, D.P., Harris, A.M., Bevan, D.J., Simmons, L.A., Azevedo, P.A., Cho, C.Y., 2000. Feather meals and meat and bone meals from different origins as protein sources in rainbow trout (Oncorhynchus mykiss) diets. Aquaculture 181, 281-291.

Caetano, D.L.F., de Oliveira, E.F., Zawadzki, C.H., 2016. Fish species indicators of environmental quality of neotropical streams in outhern Brazil, upper Paraná river basin. Acta Ichthyol. Piscat. 46, 87-96.

Camargo, M.M.P., Martinez, C.B.R., 2007. Histopathology of gills, kidney and liver of a neotropical fish caged in na urban stream. Neotrop. Ichthyol. 5, 327-336.

Canzi, C., 2011. Avaliação da utilização do mexilhão dourado (Limnoperna fortunei Dunker, 1857) na elaboração de farinha para alimentação da tilápia (Oreochromis niloticus Linnaeus, 1758). (Available at:) http://tede.unioeste.br/bitstream/tede/ 1808/1/Carla\%20Canzi.pdf. (Acess 12 August 2017).

Castro, R.M.C., Casatti, L., Santos, H.F., Melo, A.L.A., Martins, L.S.F., Ferreira, K.M., Gibran, F.Z., Benine, R.C., Carvalho, M., Ribeiro, A.C., Abreu, T.X., Bockmann, F.A., Dardis, G.Z.P., Stopiglia, R., Langeani, F., 2004. Estrutura e composição da ictiofauna de riachos da bacia do Rio Grande, no Estado de São Paulo, Sudeste do Brasil. Biota 
Neotrop. 4 (1), 1-39.

Cetra, M., Ferreira, F.C., 2016. Fish-based Index of Biotic Integrity for wadable streams from Atlantic Forest of south São Paulo State, Brazil. Acta Limnol. Bras. 28, 1-9.

Chen, G., Zhang, M., Zhang, J., Dong, H., Zhou, H., Tang, B., Huang, J., Shi, G., Jiang, L., $\mathrm{Wu}, \mathrm{Z} ., 2$ 2009. The effects of different levels of dietary protein and L-carnitine on blood sugar and lipids of the new GIFT strain of juvenile Nile tilapia (Oreochromis niloticus). Sci. World J. 9, 1197-1205.

Clarke, K.R., 1993. Non-parametric multivariate analysis of changes in community structure. Aust. J. Ecol. 18, 117-143.

Correa, S.B., Winemiller, K.O., 2014. Niche partitioning among frugivorous fishes in response to fluctuating resources in the Amazonian floodplain forest. Ecology 95 (1), 210-224.

Delariva, R.L., Hahn, N.S., Kashiwaqui, E.A.L., 2013. Diet and trophic structure of the fish fauna in a subtropical ecosystem: impoundment effects. Neotrop. Ichthyol. 11, 891-904.

Demétrio, J.A., Gomes, L.C., Latini, J.D., Agostinho, A.A., 2012. Influence of net cage farming on the diet of associated wild fish in a Neotropical reservoir. Aquaculture 330-333, 172-178.

Edwards, P., 2015. Aquaculture environment interactions: past, present and likely future trends. Aquaculture 447, 2-14.

FAO, 2016. Novo relatório da FAO aponta que produção da pesca e aquicultura no Brasil deve crescer mais de $100 \%$ até 202 . http://www.fao.org/brasil/noticias/detailevents/pt/c/423722/ (acesso 10 November 2016).

Felsing, M., Glencross, B., Telfer, T., 2005. Preliminary study on the effects of exclusion of wild fauna from aquaculture cages in a shallow marine environment. Aquaculture 243, 159-174.

Fernandez-Jover, D., Lopez-Jimenez, J.A., Sanchez-Jerez, P., Bayle-Sempere, J.T., Casalduero, F.G., Martinez-Lopez, F.J., Dempster, T., 2007. Changes in body condi tion and fatty acid composition of wild Mediterranean horse mackerel (Trachurus mediterraneus, Steindachner, 1868) associated to sea cage fish farms. Mar. Environ. Res. 63, 1-18.

Fernandez-Jover, D., Sanchez-Jerez, P., Bayle-Sempere, J.T., Valle, C., Dempster, T., 2008. Seasonal patterns and diets of wild fish assemblages associated with mediterranean coastal fish farms. ICES J. Mar. Sci. 65, 1153-1160.

Fernandez-Jover, D., Arechavala-Lopez, P., Martinez-Rubio, L., Tocher, D.R., BayleSempere, J.T., Lopez-Jimenez, J.A., Martinez-Lopez, F.J., Sanchez-Jerez, P., 2011. Monitoring the influence of marine aquaculture on wild fish communities: benefits and limitations of fatty acid profiles. Aquacult. Environ. Interact. 2, 39-47.

Garcia, F., Kimpara, J.M., Valenti, W.C., Ambrosio, L.A., 2014. Emergy assessment of tilapia cage farming in a hydroelectric reservoir. Ecol. Eng. 68, 72-79.

Gerking, S.D., 1994. Feeding Ecology of Fish. Academic Press, London.

Gomes, I.T., López, A.C.C., Paiva, V.L.G.S., Held, B., Quinaglia, G.A., Sá, L.R.M., 2016. Avaliação macroscópica comparada entre acarás (Geophagus brasiliensis) e tilápias como bioindicadores de poluição ambiental da represa Billings. Rev. Educ. Cont. Med. Vet. Zootec. 14, 68-69.

Graça, W.J., Pavanelli, C.S., 2007. Peixes da planície de inundação do alto rio Paraná e áreas adjacentes. EDUEM, Maringá.

Hahn, N.S., Fugi, R., 2007. Alimentação de peixes em reservatórios brasileiros: alterações e consequências nos estágios iniciais do represamento. Oecol. Bras. 11, 469-480.

Hammer, D.A., Harper, T., Ryan, P.D., 2001. PAST: Paleontological Statistics Software package for education and data analysis. Palaeontol. Electronica 4, 1-9.

Hellawell, J.M., Abel, R., 1971. A rapid volumetric method for the analysis of the food fishes. J. Fish Biol. 3, 20-37.

Hepher, B., 1989. Principles of fish nutrition. In: Shilo, M., Saring, S. (Eds.), Fish Culture in Carm Water Systems, Problems; Trends. CRC, Boca Raton, pp. 121-142.

Honorato, C.A., Cruz, C. da, Carneiro, D.J., Machado, M.R.F., Nascimento, C.A., Saturnino, K.C., 2014. Histology liver in Nile tilapia (Oreochromis niloticus) fed diets with fish silage. Pesqui. Vet. Bras. 34, 64-68.

Hyslop, E.J., 1980. Stomach contents analysis: a review of methods and their application. J. Fish Biol. 17, 411-429.

IBGE, 2015. Produção pecuária municipal. Prod. Pecu. Munic. 43, 1-49.

Ibañez, C., Belliard, J., Hughes, R.M., Irz, P., Kamdem-Toham, A., Lamouroux, N., Tedesco, P.A., Oberdorff, T., 2009. Convergence of temperate and tropical stream fish assemblages. Ecography 32, 658-670.

Kirchner, R.M., Chaves, M.A., Silinske, J., Essi, L., Scherer, M.E., Durigon, E.G., 2016. Análise da produção e comercialização do pescado no Brasil. Rev. Agroamb. On-line 10 (2), 168-177.

Kubitza, F., 2015. Aquicultura no Brasil: principais espécies, áreas de cultivo, rações, fatores limitantes e desafios. Panor. Aquic. 25, 10-23.

Kumar, V., Abbas, A.K., Aster, J.C., 2013. Patologia Básica. Elsevier, Rio de Janeiro.

Langeani, F., Corrêa e Castro, R.M., Oyakawa, O.T., 2007. Diversidade da ictiofauna do Alto Rio Paranê: composiáço atual e perspectivas futuras. Biota Neotrop. 7, 181-197.

Le Cren, E.D., 1951. The length-weight relationship and seasonal cycle in gonad weight and condition in the perch (Perca fluviatilis). J. Anim. Ecol. 20, 201-219.

Lee, J.W., Kim, J.W., Riu, N., De Moniello, G., Hung, S.S.O., 2012. Histopathological alterations of juvenile green (Acipenser medirostris) and white sturgeon (Acipenser transmontanus) exposed to graded levels of dietary methylmercury. Aquat. Toxicol. 109, 90-99.

Liu, H., Zhu, X., Yang, Y., Han, D., Jin, J., Xie, S., 2016. Effect of substitution of dietary fishmeal by soya bean meal on different sizes of gibel carp (Carassius auratus gibelio): nutrient digestibility, growth performance, body composition and morphometry. Aquacult. Nutr. 22, $142 \mathrm{e} 57$.

Lowry, O.H., Rosenbrough, N.J., Farr, A.L., Randal, R.J., 1951. Protein measurement with Folin phenol reagent. J. Biol. Chem. 193, 265-275.

Mallasen, M., Carmo, C.F., Tucci, A., Barros, H.P., Rojas, N.E.T., Fonseca, F.S., 2012 Qualidade da Água em Sistema de Piscicultura em Tanques-rede no Reservatório de
Ilha Solteira, SP. Bol. Inst. Pesca (Online) 38, 15-30.

Mela, M., Randi, M.A.F., Ventura, D.F., Carvalho, C.E.V., Pelletier, E., Oliveira Ribeiro, C.A., 2007. Effects of dietary methylmercury on liver and kidney histology in the neotropical fish Hoplias malabaricus. Ecotoxicol. Environ. Saf. 68, 426-435.

Milligan, C.L., Girard, S.S., 1993. Lactate metabolism in rainbow trout. J. Exp. Biol. 180, $175-193$.

Mommsen, T.P., 2001. Paradigms of growth in fish. Comparative biochemistry and physiology. Comp. Biochem. Physiol. B: Biochem. Mol. Biol. 129, 207-219.

Morais, C.R., Carvalho, S.M., Araujo, G.R., Souto, H.N., Bonetti, A.M., Morelli, S., Campos Júnior, E.O., 2016. Assessment of water quality and genotoxic impact by toxic metals in Geophagus brasiliensis. Chemosphere 152, 328-334.

Moretto, E.M., Marciano, F.T., Velludo, M.R., Fenerich-Verani, N., Espíndola, E.L.G., Rocha, O., 2008. The recent occurrence, establishment and potential impact of Geophagus proximus (Cichlidae: Perciformes) in the Tiête River reservoirs: an Amazonian fish species introduced in the Paraná Basin (Brazil). Biodivers. Conserv. 17, 3013-3025.

Mugnai, R., Nessimian, J.L., Baptista, D.F., 2010. Manual de identificação de macroinvertebrados aquáticos do Estado do Rio de Janeiro. Technical Boocks, Rio de Janeiro.

Nabirye, H., Mwebaza-Ndawula, L., Bugenyi, F.W.B., Muyodi, F.J., 2016. The evaluation of cage fish farming effects on water quality using selected benthic macro-invertebrate community parameters in the napoleon gulf, northern Lake Victoria. IJFAS 4, 42-50.

Ning, L.J., He, A.Y., Lu, D.L., Li, J.M., Qiao, F., Li, D.L., Zhang, M.L., Chen, L.Q., Du, Z.Y., 2017. Nutritional background changes the hypolipidemic effects of fenofibrate in Nile tilapia (Oreochromis niloticus). Sci. Rep. 7, 41706.

Oliveira, E.F., Goulart, E., Breda, L., Minte-Vera, C., De Sousa, L.R., Vismara, M.R., 2010 Ecomorphological patterns of the fish assemblage in a tropical floodplain: effects of trophic, spatial, and phylogenetic structures. Neotrop. Ichthyol. 8, 569-586.

Oliveira Ribeiro, C.A., Reis Filho, H.S., Grotzner, S.R., 2012. Técnicas e métodos para utilização prática de microscopia. Editora Santos, São Paulo.

Ortega, J.C.G., Júlio Jr., H.F., Gomes, L.C., Agostinho, A.A., 2015. Fish farming as the main driver of fish introductions in Neotropical reservoirs. Hydrobiologia 746, $147-158$.

Paulino, M.G., Benze, T.P., Sadauskas-Henrique, H., Sakuragui, M.M., Fernandes, J.B., Fernandes, M.N., 2014. The impact of organochlorines andmetals onwild fish living in a tropical hydroelectric reservoir: bioaccumulation and histopathological biomarkers. Sci. Total Environ. 497-498, 293-306.

Piaoping, Z., Mengqiang, W., Fengjun, X., Dong-Fang, D., Qicun, Z., 2016. Effects of dietary carbohydrate to lipid ratios on growth performance, digestive enzyme and hepatic carbohydrate metabolic enzyme activities of large yellow croaker (Larmichthys crocea). Aquaculture 452, 45-51.

Pielou, E.C., 1975. Ecological Diversity. Wiley, New York.

Poleksic, V., Mitrovic-Tutundzic, V., 1994. Fish gills as a monitor of sublethal and chronic effects of pollution. In: Müller, R., Lloyd, R. (Eds.), Sublethal and Chronic Effects of Pollutants on Freshwater Fish. Fishing News Books, Oxford, pp. 339-352.

R Development Core Team, 2015. R, a Language and Environment for Statistical Computing. Version 3.2.3. R Foundation for Statistical Computing, Austria.

Ramos, I.P., Vidotto-Magnoni, A.P., Carvalho, E.D., 2008. Influence of cage fish farming on the diet of dominant fish species of a Brazilian reservoir (Tietê River, High Paraná River basin). Acta Limnol. Bras. 20, 245-252.

Ramos, I.P., Brandão, H., Zanatta, A.S., Zica, E.O.P., Da Silva, R.J., De Rezende-Ayroza, D.M.M., Carvalho, E.D., 2013. Interference of cage fish farm on diet, condition factor and numeric abundance on wild fish in a Neotropical reservoir. Aquaculture 414-415, 56-62.

Ramos, I.P., Franceschini, L., Zica, É.O.P., Carvalho, E.D., Silva, R.J., 2014. The influence of cage farming on infection of the corvine fish Plagioscion squamosissimus (Perciformes: Sciaenidae) with metacercariae of Austrodiplostomum compactum (Digenea: Diplostomidae) from the Chavantes reservoir, São Paulo State, Brazil. J. Helminthol. 88, 342-348.

Randall, D., Burggren, W., French, K., 2000. ECKERT Fisiologia animal - mecanismos e adaptações, fourth ed. Guanabara Koogan, Rio de Janeiro.

Roberts, R.J., 1989. Fish Pathology, second ed. Braillière Tindall, London.

Ségade, Á., Robaina, L., Novelli, B., Otero-Ferrer, F., Molina Domínguez, L., 2015. Effect of the diet on lipid composition and liver histology of short snout seahorse Hippocampus hippocampus. Aquacult. Nutr. 22, 1-8.

Saraiva, A., Costa, J., Serrão, J., Cruz, C., Eiras, J.C., 2015. A histology-based fish health assessment of farmed seabass (Dicentrarchus labrax L.). Aquaculture 448, 375-381.

Schmidt-Nielsen, K., 1999. Fisiologia animal: adaptação e meio ambiente. Santos, São Paulo.

Schulter, E.P., Vieira Filho, J.E.R., 2017. Evolução da piscicultura no Brasil: Diagnóstico e desenvolvimento da cadeia produtiva de Tilápia. Texto para discussão/Instituto de Pesquisa Econômica Aplicada- Brasília. Ipea, Rio de Janeiro.

Schwaiger, J., Wanke, R., Adam, S., Pawert, M., Wolfgang, H., Triebskorn, R., 1997. The use of histopathological indicators to evaluate contaminant-related stress in fish. J. Aquat. Ecosyst. Stress Recovery 6, 75-86.

Shiogiri, N.S., Paulino, M.G., Carraschi, S.P., Baraldi, F.G., da Cruz, C., Fernandes, M.N., 2012. Acute exposure of a glyphosate-based herbicide affects the gills and liver of the Neotropical fish, Piaractus mesopotamicus. Fnviron. Toxicol. Pharmacol. 34, 388-396.

Silva, D.S., Lucotte, M., Roulet, M., Poirier, H., Mergler, D., Santos, E.O., Crossa, M., 2005 Trophic structure and bioaccumulation of mercury in fish of three natural lakes of the brazilian amazon. Water Air Soil Pollut. 165, 77-94.

Silva, J.C., Gubiani, É.A., Neves, M.P., Delariva, R.L., 2017. Coexisting small fish species in lotic neotropical environments: evidence of trophic niche differentiation. Aquat. Ecol. 51 (2), 275-288.

Stentiford, G.D., Longshaw, M., Lyons, B.P., Jones, G., Green, M., Feist, S.W., 2003. 
Histopathological biomarkers in estuarine fish species for the assessment of biological effects of contaminants. Mar. Environ. Res. 55, 137-159.

Sumpter, J.P., Scott, A.P., Baynes, S.M., Witthames, P.R., 1984. Early stages of the reproductive cycle in virgin female rainbow trout (Salmo gairdneri Richardson). Aquaculture 43, 235-242.

Takashima, F., Hibiya, T., 1995. An Atlas of Fish Histology: Normal and Pathological Features. Kodansha, Tokyo.

Tiwary, B.K., Kirubagaran, R., Ray, A.K., 2002. Testosterone triggers the brain-pituitarygonad axis of juvenile female catfish (Heteropneustes fossilis Bloch) for precocious ovarian maturation. Gen. Comp. Endocrinol. 126, 23-29.

Tripathi, S., Srivastav, A.K., 2010. Liver profile of rats after long-term ingestion of different doses of chorpyrifos. Pest. Biochem. Physiol. 97, 60-65.

Tundisi, J.G., 2007. Exploração do potencial hidrelétrico da Amazônia. Estudos Avançados 59, 109-117.

Tyler, C.R., Sumpter, J.P., Witthames, P.R., 1990. The dynamics of oocyte growth during vitellogenesis in the rainbow trout (Oncorrhynchus mykiss). Biol. Reprod. 43, 202-209.

Uglem, I., Karlsen, O., Sanchez-Jerez, P., Saether, B.-S., 2014. Impacts of wild fishes attracted to open-cage salmonid farms in Norway. Aquacult. Environ. Interact. 6, 91-103.

Verlag, G.F., 1982. An Atlas of Fish Histology: Normal and Pathological Features. Kodansha, Tokyo.

Vidotto, A.P., Carvalho, E.D., 2009. Aquatic insects as the main food resource of fish the community in a Neotropical reservoir. Neotrop. Ichthyol. 7, 701-708.

Yancheva, V., Velcheva, I., Stoyanova, S., Georgieva, E., 2016. Histological biomarkers in fish as a tool in ecological risk assessment and monitoring programs: a review. Appl. Ecol. Environ. Res. 14, 47-75.

Zanatta, A.S., Ramos, I.P., Silva, R.J., Langeani, F., Carvalho, E.D., 2010. Pisces, Siluriformes, Ictaluridae, Ictalurus punctatus (Rafinesque, 1818): first record in middle Paranapanema river reservoir, aquaculture and exotic species dispersion. Check List 6 (4), 589-591.

Zhang, Y., Sun, Z., Wang, A., Ye, C., Zhu, X., 2017. Effects of dietary protein and lipid levels on growth, body and plasma biochemical composition and selective gene expression in liver of hybrid snakehead (Channa maculata $\bigcirc \times$ Channa argus ${ }^{\top}$ ) fingerlings. Aquaculture 468, 1-9. 